\title{
The New Mastitis Agents Emerged in Cattle in Turkey and An Investigation of Their Antimicrobial Susceptibility
}

\author{
Beytullah KENAR $^{*}$, Adil AKSOY ${ }^{2}$, Zahide $\mathrm{KÖSE}^{3}$ \\ 1 Afyon Kocatepe University, Faculty of Veterinary Medicine, Department of Microbiology, 03200, Afyonkarahisar, Turkey \\ ${ }_{2}^{2}$ Aksaray University, Eskil Vocation School, Aksaray, Turkey \\ ${ }^{3}$ Afyon Kocatepe University, Faculty of Veterinary Medicine, Department of Microbiology, 03200, Afyonkarahisar, Turkey
}

\begin{abstract}
There are new emerging cattle mastitis agents that have become a major burden economically on the dairy industry because of their negatively affects on production and quality in dairy cattle farming in Turkey,. To overcome this emerged problem, antimicrobials are adopted in this sector to prevent and administrate mastitis and other bacterial infections affecting cattle in the country. Nevertheless, the occurrence of antimicrobial resistance (AMR) is increasing in both animal and human contaminants. The occurrence and features of AMR of the emerging cattle mastitis agents in dairy cattle in Turkey, have been manifested. As a result, the goal of this research was to assess secluded emerging cattle mastitis agents in Turkey and to appraise the antimicrobial susceptibility of these pathogens. Sixty one milk samples from cattle wwith mastitis were collected between 2014 and 2018 for assessment of clinical mastitis in diagnostic and analysis laboratory of Faculty of Veterinary Medicine, Afyon Kocatepe University. Twenty five microorganism species arised as cattle mastitis agents were assessed in these milk samples. The outcomes of the present study identified the necessity for advancements in antimicrobial stewardship as well as infection administration plans in Turkish farms to decrease the occurence of AMR. VITEK Compact ${ }^{\circledR} 2$ systemmethod showed that Streptococcus uberis had the maximum AMR while Globicatella sulfidifaciens had the minimum AMR. The study depicts that the number of cattle mastitis is directly proportional to the size of the herd.
\end{abstract}

Keywords: Cattle, mastitis, new agent, antimicrobial resistance.

\section{Türkiye'de Yeni Sı̆̆ır Mastitis Ajanları ve Antimikrobiyal Duyarlılıklarının Araştırılması}

\section{ÖZ}

Türkiye'deki sütçü ineklerinin üretim ve kalitesine olumsuz yönde etkileyen ve süt endüstrisine ekonomik olarak büyük bir zarar oluşturan yeni ortaya çıkan sığır mastitis etkenleri bulunmaktadır. Giderek artan bu sorunun üstesinden gelmek için, bu sektörde mastitis ve ülkedeki inekleri etkileyen diğer bakteriyel enfeksiyonların önlenmesi ve yönetilmesi amacıyla antimikrobiyaller kullanılmaktadır. Bununla birlikte, antimikrobiyal direncin (AMR) oluşumu hem hayvan hem de insan kontaminantlarında artmaktadır. Türkiye'deki sütçü ineklerinden ortaya çıkan sığır mastitis etkenlerinde antimikrobiyal direncin oluşumu ve özellikleri açıç̧a ortaya konmuştur. Sonuç olarak, bu araştırmanın amacı, Türkiye'de ilk kez tespit edilen inek mastitis etkenlerini ve bu patojenlerin antimikrobiyal duyarlılı̆̆ını değerlendirmektir. Bu araştırmada Afyon Kocatepe Üniversitesi Veteriner Fakültesi Teşhis ve Analiz Laboratuarında klinik mastitisin değerlendirilmesi için $2014-2018$ yılları arasında 61 adet mastitisli süt örneği incelenmiştir. Bu süt örneklerinden Türkiye’de ilk kez izole edilen 25 sığır mastitis ajanı değerlendirilmiştir.. Mevcut araştırmanın sonucu, AMR'nin gelişimini azaltmak için Türkiye çiftliklerindeki enfeksiyon yönetiminin planlanmasının yanı sıra antimikrobiyal geliştirilmesinin gerekliliğini de ortaya koymuştur. VITEK Compact ${ }^{\circledR} 2$ yöntemi Streptococcus uberis'in maksimum AMR, Globicatella sulfidifaciens'in ise minimum AMR geliştirdiğini göstermiştir. Çalışma, ortaya çıkan sığır mastitis sayısının doğrudan sürü büyüklüğü ile orantılı olduğunu da ortaya koymuştur. Anahtar Kelimeler: İnek, mastitis, yeni ajan, antimikrobiyal direnç.

\footnotetext{
To cite this article: Kenar B. Aksoy A. Köse Z. The New Mastitis Agents Emerged in Cattle in Turkey and An Investigation of Their Antimicrobial Susceptibility. Kocatepe Vet J. (2019) 12(4):400-406.
}

\author{
Submission: 05.09.2019 Accepted: 05.10.2019 Published Online: 09.10.2019 \\ ORCID ID; BK: 0000-0001-6573-680X, AA: 0000-0002-1521-3100, ZK: 0000-0002-2914-1582 \\ *Corresponding author e-mail: bkenar@aku.edu.tr
}




\section{INTRODUCTION}

Numerous emerging cattle mastitis agents have turned to be a critical economic liability on the dairy sector because they adversely impact milk quality and milk yield. According to Du et al. 2018, cattle mastitis is a disorder triggered by a diversity of microorganism's contaminations that result to major economic damages and loses to the breeding sector via reducing the production of milk as well as raising culling and antibiotic treatments costs (Sztachańska et al. 2016). Usually, fungal contaminations of mammary gland are instigated by yeast, of which the primary species are Candida spp.. The occurrence of mastitis happens when white blood cells are generated into the mammary gland, commonly in reaction to microorganisms attacking the teat canal or sometimes by thermal, mechanical or chemical disturbance on the udder (Sonmez and Erbas 2017). As a result, the tissue responsible for milk secretion as well as several ducts in the mammary gland are impaired because of the toxins produced by the bacteria that consequently lead to a decrease of milk quality and yield. The presence of the infection can be recognized by udder disorders like pain, tenderness, hardness, fever, skin rednessand swelling (Hosseinzadeh and Saei 2014). Measures like efficiently dairy cattle nourishment, proper housing administration, culling of frequentlydiseased cows and milking sanitation to enhance the well-being of the cattle are significant in the regulation of herd mastitis stages. The determination of the mastitis agents is significant when choosing the correct antimicrobial treatment (Martin et al. 2018).

In the current study, 25 species of emerging dairy cattle mastitis agents were assessed in Turkey. These emerging mastitis agents are commonly located in udder tissues (Das et al. 2017). Mastitis agents that are spread from one cattle to another are referred to as contagious pathogens while those that are present in the herd's vicinities are called environmental pathogens. The differentiation between these two types of mastitis pathogens is significant in examining the problems present in the cattle as well as the control measures that might be adapted to treat or decrease this disorder (Martí-Carrizosa et al. 2015). Contagious agents adhere simply to the cattle skin, inhabiting the end of the teat and develop into the teat canal where the contamination happens. Due to this, post-milking disinfection of the teat, as well as dry cow treatment play a significant function in regulating contagious mastitis (Xiao et al. 2014). Regarding the environmental mastitis, the agents can gain access to the teat canal forcefully in the course of milking like when liner slippage happens (Rocha et al. 2016). The environmental agents of mastitis do not commonly possess identical capability as contagious pathogens to attach to as well as to colonize the teat (Kadariya et al. 2014). As a result, dry cattle treatment has little value in their regulations since these types of contaminations do not carry from one lactation to another (Sonmez and Erbas 2017). Cattle mastitis agents can contaminate the cows when they are lactating as well as during the dry season. It is thus crucial to recognize and determine the causes of these infections since the treatment, control, and prevention methods of the agent's impacts can vary based on if the contamination happens when the cow is lactating or dry (Eldesouky et al. 2016). Identification of agents which cause cattle mastitis to enhance the selection of the appropriate antimicrobial therapy is then conducted. Antimicrobials are implemented in the dairy sector for control and prevention of mastitis as well as other bacterial disorders impacting dairy cows. Reliance on antimicrobials has turned out to be a broad spectacle in the dairy industry (Cheng et al. 2019). Beta-lactam antibiotics are usually adopted in handling cattle mastitis agents. Bacterial opposition to beta-lactam mechanisms comprises of generation protein which is a low-affinity penicillin-binding as well as secretion of beta-lactamases (Ksouri et al. 2015). Antibacterial agents from crops are substantial sources of new antibiotics compounds and efflux pump inhibitors which target bacterial virulence or can be adopted in mixture with other prevailing drugs (Sartori et al. 2014). The plants generate a significant constituent of ethno-veterinary remedy that is implemented in the therapy of diverse disorders such as bovine mastitis (Sağlam et al. 2017). Nevertheless, antimicrobial resistance (AMR) arises when the pathogens are capable of overcoming the impact of antimicrobials which were efficient previously (Zhang et al. 2018). In Turkey, AMR remains a substantial threat in the dairy industry. According to WHO (2015), AMR is one of the biggest dangers to international food security, health and progression. In many nations including Turkey, variations in the absolute and relative significance of the primary mastitis agents have been detected over time, possibly due to the marked modifications in the dairy sector (Erbas et al. 2017). The objective of the current assessment was to examine isolated emerging cattle mastitis agents in Turkey and to evaluate the antimicrobial susceptibility of these pathogens.

\section{MATERIAL and METHODS}

\section{Culture of Milk Samples}

The current study was conducted according to the guidelines of the Afyon Kocatepe University, Faculty of Veterinary Medicine diagnostic and analysis. A total of 61 milk samples of cattle with mastitis were collected between 2014 and 2018 in diagnostic and analysis laboratory offaculty of Veterinary Medicine in Afyon Kocatepe University for analysis of clinical mastitis agents. All cultural procedures of milk samples were pursued in line with Gao et al. (2017). In a precise manner, $100 \mu \mathrm{l}$ of milk sample was plated on blood agar (Oxoid, CM0055) supplemented with 
7\% sheep blood, on C.L.E.D Medium (CM0301 Oxoid) and on Eosin Methylene Blue agar (Oxoid, CM0069) plates. The plates were then incubated aerobically at $37^{\circ} \mathrm{C}$ for $24-48$ hours. All samples were considered as culture positive in the case that one or more colonies were observed. The samples which had two different bacterial colonies were put into a group of mixed culture while those which had more than two colonies were assumed as contaminated (Verbeke et al. 2014).

\section{Identification of Microorganisms Colony characteristics}

Pigmentation of colonies on blood agar was initially evaluated by the reference of Quin et al. (1999). On blood agar plates, the beta-hemolytic Smooth (S) colonies with a golden yellow color was assumed as Staphylococcus aureus whereas non-hemolytic porcelainwhite pigmented colonies were considered as Staphylococcus epidermidis. The colonies of Staphylococcus saprophyticus show a white or bright pigmentation without hemolysis on blood agar.

\section{Catalase test}

This test provide to detect if a particular bacterial isolate is able to produce catalase enzyme which is produced by microorganisms that live in oxygenated environments to neutralize toxic forms of oxygen metabolites such as $\mathrm{H}_{2} \mathrm{O}_{2}$. To test enzymatic activity, a small inoculum of a bacterial isolate is mixed into hydrogen peroxide solution $(3 \%)$ on a dry glass microscobe slide and is observed for the rapid elaboration of oxygen bubbles (Quinn et al. 1999). This test was used in the current study as a way of distinguishing among Gram $(+)$ cocci. The members of Enterococcus and Streptococcus in general are catalasenegative while those the genus Stapbylococcus are catalase-positive.

\section{Coagulase test}

Coagulase test is used to differentiate $S$. aureus (positive) from Coagulase Negative Staphylococcus (CNS). Coagulase is an enzyme produced by $S$. aureus that converts fibrinogen in plasma to fibrin. $S$. aureus produces two forms of coagulase, bound and free. Slide coagulase test is done to detect bound coagulase or clumping factor while tube coagulase test is done to detect free coagulase. In this study, slide coagulase test is initially adopted to screen bound coagulase of $S$. aureus as well as the tube coagulase test was used for further confirmation of free coagulase (Quinn et al. 1999). During the slide test, the sample on the test was added to a rabbit plasma and kept constant at $37^{\circ} \mathrm{C}$ for quite a while. In the occurrence of a positive outcome, clot formation occurs within 4 hours. A virulent strain indicates an adverse effect. In the current study, the slides were separated into units using a grease pencil. One was labeled as 'test' while the other as 'control.' Each of the samples was placed a small drop of condensed water on each area.
The two colonies of Staphylococcus were emulsified on the blood agar plate on each drop as a way of making a smooth suspension (Schukken et al. 2014). The 'test' suspension was treated with a drop of citrated plasma after which it was mixed with a needle. It is advisable to keep the other drop as it is since it is a control experiment. The control suspension was the one used to rule out false positivity as a result of autoagglutination. There was clumping of cocci within the first 5-10 seconds which indicated a positive remark.

\section{Gram properties}

A study was done as a way of evaluating the VITEK 2 Gram staining Gram (-) and Gram (+) with an identification card of VITEK 2 automated identification system (Kaur et al. 2016). This card was crucial in the identification of fermenting and non-fermenting agent organisms such as Burkbolderia psendomallei and Burkbolderia cepacia .

\section{Recovery of Isolates}

The initial steps included bacterial recovery on a tryptic soy agar plates which were then incubated at a $37^{\circ} \mathrm{C}$ for a whole day. Colonies were then transferred into Mueller-Hinton Broth medium which contained a $5 \%$ bovine serum added for Streptococcus spp. The mix was shaken at a constant temperature for 12 hours. A turbidimeter for bacteria was utilized in adjusting the suspension to a $0.5 \mathrm{McF}$ arland standard density.

\section{Antibiogram tests}

Phenotypic assessment of antimicrobial susceptibility was achieved via the use of microdilution method used in line with the Clinical Laboratory and Standards Institute (CLSI) guidelines. Antimicrobials which were evaluated for Gram (+) bacteria included the following: Penicillin/Novobiocin (Bioanalyse 0.01/0.03 mg/ml), Oxytetracycline (Bioanalyse 0.03 $\mathrm{mg} / \mathrm{ml}$ ), Danofloxacin (Bioanalyse $5 \mu \mathrm{g} / \mathrm{ml}$ ), Ceftiofur (Oxoid $0.03 \quad \mathrm{mg} / \mathrm{ml}$ ), Lincomycin/Spectinomycin (Oxoid $0.109 \mathrm{mg} / \mathrm{ml}$ ), Gentamicin (Bioanalyse $0.01 \mathrm{mg} / \mathrm{ml}$ ), Oxytetracycline (Bioanalyse $0.03 \mathrm{mg} / \mathrm{ml}$ ), Erythromycin (Bioanalyse $0.015 \mathrm{mg} / \mathrm{ml}$ ) and Amoxicillin/Clavulanic Acid (Bioanalyse 0.02/0.01 $\mathrm{mg} / \mathrm{ml}$ ). The test was made according to CLSI (2016) using Mueller Hinton Agar (CM 0337 Oxoid) medium to test bacterial susceptibility against to different concentration of antibiotics emdedded in discs.

\section{RESULT}

The microorganisms identified in this study and antibiyogram test results are shown in Table 1a,b. In the test out of 61 samples, 11 characterized as Gram $(+)$ organisms. In addition, 50 isolates of Gram (-) fermenting and non-fermenting Burkbolderia and $B$. 
pseudomallei were screened by Gram stain. Out of the 61 samples were investigated, S. aureus, S. haemolyticus E. coli, and S. epidermis were the most emerging cattle mastitis. The current study shows that E. coli and Klebsiella spp. seem to be resistant to Amoxycillin-Clavulanic Acid (76\% and 34\%) which is slightly high than reports done before. The prevalence of Escherichia coli was also lower.

The identified microorganisms include Staphylococcus aureus ( $\mathrm{n}=4)$, Staphylococcus haemolyticus $(\mathrm{n}=5)$, Candida kefyr $(\mathrm{n}=1)$, Lactococcus garvieae $(\mathrm{n}=1)$, Globicatella sulfidifaciens $(\mathrm{n}=1)$, Aerococcus viridans $(\mathrm{n}=2)$, Brevibacillus choshinensis $(\mathrm{n}=2), \quad$ Bacillus licheniformis $(\mathrm{n}=1)$, Pseudomonas aeruginosa $(\mathrm{n}=1)$, Aerococcus viridans $(\mathrm{n}=2)$, Streptococcus uberis $(\mathrm{n}=1)$, Leuconostoc mesenteroides $(\mathrm{n}=1)$, Micrococcus luteus $(\mathrm{n}=1)$, Burkholderia cepacia $(\mathrm{n}=1)$, Escherichia coli (13), Pasteurella multocida ( $\mathrm{n}=1$ ), Sphingomonas paucimobilis $(\mathrm{n}=3)$, Kocuria rosea $(\mathrm{n}=1)$, Kocuria rhizophila $(\mathrm{n}=3)$, Kocuria kristinae $(\mathrm{n}=1)$, Kocuria varians $(\mathrm{n}=1)$, Staphylococcus chromogenes $(\mathrm{n}=1)$, Staphylococcus simulans $(\mathrm{n}=2)$, Staphylococcus saprophyticus $(\mathrm{n}=3)$ and Staphylococcus epidermidis $(\mathrm{n}=8)$. Thus, 25 different bacteria were identified in mastitic milk samples of cattle and this is the first in Turkey.

Table 1a. Microorganisms isolated in the present study and antibiogram test results of isolates

\begin{tabular}{|c|c|c|c|c|c|c|c|c|c|}
\hline \multirow[t]{2}{*}{ Year } & \multirow[b]{2}{*}{ Bacteria } & \multicolumn{8}{|c|}{ Antibiotics } \\
\hline & & 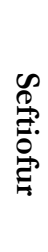 & 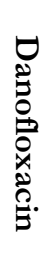 & 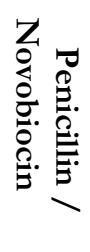 & 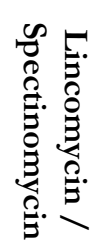 & 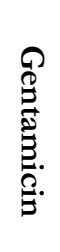 & 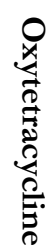 & 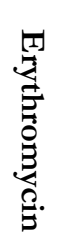 & 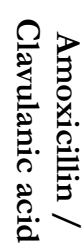 \\
\hline \multirow{5}{*}{2014} & Staphylococcus aureus & 1 & 1 & 1 & 3 & 3 & 2 & 3 & 1 \\
\hline & Staphylococcus haemolyticus & 0 & 0 & 0 & 0 & 1 & 0 & 3 & 0 \\
\hline & Staphylococcus haemolyticus & 0 & 0 & 0 & 0 & 1 & 0 & 2 & 0 \\
\hline & Staphylococcus haemolyticus & 0 & 0 & 0 & 0 & 1 & 0 & 2 & 2 \\
\hline & Staphylococcus haemolyticus & 1 & 2 & 1 & 0 & 2 & 1 & 3 & 2 \\
\hline \multirow{7}{*}{2015} & Staphylococcus epidermidis & 1 & 3 & 2 & 2 & 3 & 1 & 3 & 2 \\
\hline & Staphylococcus aureus & 3 & 1 & 3 & 3 & 2 & 1 & 3 & 1 \\
\hline & Staphylococcus simulans & 3 & 1 & 2 & 3 & 0 & 2 & 3 & 2 \\
\hline & Staphylococcus simulans & 0 & 0 & 0 & 1 & 0 & 2 & 2 & 3 \\
\hline & Staphylococcus saprophyticus & 2 & 0 & 0 & 1 & 0 & 1 & 3 & 1 \\
\hline & Staphylococcus saprophyticus & 2 & 1 & 0 & 1 & 0 & 1 & 2 & 1 \\
\hline & Staphylococcus saprophyticus & 0 & 0 & 0 & 0 & 0 & 2 & 0 & 2 \\
\hline \multirow{25}{*}{2016} & Kocuria rosea & 3 & 3 & 3 & 3 & 3 & 3 & 3 & 3 \\
\hline & Pasteurella multocida & 3 & 2 & 3 & 3 & 2 & 3 & 2 & 3 \\
\hline & Leuconostoc mesenteroides & 3 & 2 & 3 & 0 & 0 & 2 & 0 & 3 \\
\hline & Staphylococcus aureus & 3 & 3 & 3 & 3 & 3 & 3 & 3 & 3 \\
\hline & Streptococcus uberis & 2 & 1 & 3 & 1 & 2 & 0 & 0 & 3 \\
\hline & Aerococcus viridans & 3 & 3 & 3 & 3 & 3 & 3 & 3 & 3 \\
\hline & Pseudomonas aeruginosa & 3 & 3 & 0 & 3 & 3 & 2 & 2 & 0 \\
\hline & Bacillus licheniformis & 0 & 0 & 0 & 2 & 0 & 0 & 0 & 1 \\
\hline & Staphylococcus aureus & 3 & 3 & 3 & 3 & 3 & 3 & 3 & 3 \\
\hline & Escherichia coli & 3 & 0 & 2 & 1 & 3 & 3 & 0 & 1 \\
\hline & Escherichia coli & 3 & 3 & 0 & 1 & 2 & 2 & 0 & 3 \\
\hline & Escherichia coli & 3 & 3 & 0 & 1 & 2 & 2 & 2 & 2 \\
\hline & Escherichia coli & 3 & 3 & 0 & 1 & 3 & 0 & 2 & 2 \\
\hline & Escherichia coli & 3 & 3 & 3 & 2 & 3 & 3 & 3 & 3 \\
\hline & Escherichia coli & 3 & 1 & 2 & 3 & 2 & 3 & 2 & 3 \\
\hline & Escherichia coli & 2 & 1 & 2 & 2 & 2 & 1 & 0 & 2 \\
\hline & Escherichia coli & 3 & 3 & 0 & 1 & 1 & 3 & 2 & 2 \\
\hline & Escherichia coli & 3 & 3 & 3 & 2 & 2 & 2 & 2 & 2 \\
\hline & Escherichia coli & 3 & 3 & 0 & 1 & 3 & 0 & 0 & 0 \\
\hline & Brevibacillus choshinensis & 2 & 3 & 2 & 3 & 2 & 3 & 3 & 3 \\
\hline & Brevibacillus choshinensis & 2 & 3 & 2 & 2 & 2 & 3 & 3 & 1 \\
\hline & Kocuria varians & 3 & 3 & 3 & 1 & 0 & 0 & 0 & 3 \\
\hline & Aerococcus viridans & 3 & 2 & 3 & 2 & 2 & 2 & 2 & 3 \\
\hline & Globicatella sulfidifaciens & 3 & 3 & 3 & 2 & 2 & 0 & 0 & 3 \\
\hline & Staphylococcus chromogenes & 1 & 3 & 3 & 2 & 3 & 2 & 0 & 3 \\
\hline
\end{tabular}

Note: The numbers in the table indicate AMR.

$0=$ Resistant, $1=$ Insensitive, $2=$ Moderate sensitive, $3=$ Susceptibility 
Table 1b. Microorganisms isolated in the present study and antibiogram test results of isolates

\begin{tabular}{|c|c|c|c|c|c|c|c|c|c|}
\hline \multirow[t]{2}{*}{ Year } & \multirow[b]{2}{*}{ Bacteria } & \multicolumn{8}{|c|}{ Antibiotics } \\
\hline & & $\begin{array}{l}\infty \\
\stackrel{0}{0} \\
\stackrel{B}{B} \\
\stackrel{\vec{B}}{\vec{B}}\end{array}$ & 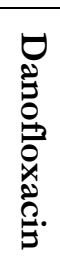 & 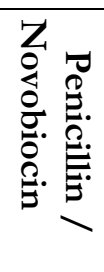 & 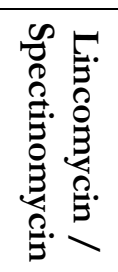 & 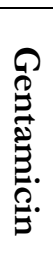 & 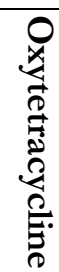 & $\begin{array}{l}\pi \\
2 \\
\vdots \\
0 \\
0 \\
0 \\
0 \\
0\end{array}$ & 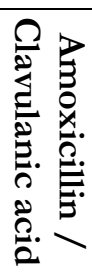 \\
\hline \multirow{14}{*}{2017} & Kocuria rbizophila & 2 & 1 & 0 & 0 & 0 & 0 & 0 & 1 \\
\hline & Sphingomonas paucimobilis & 3 & 3 & 3 & 2 & 3 & 3 & 3 & 3 \\
\hline & Sphingomonas paucimobilis & 3 & 3 & 3 & 3 & 0 & 2 & 3 & 3 \\
\hline & Staphylococcus epidermidis & 3 & 3 & 3 & 3 & 3 & 0 & 0 & 3 \\
\hline & Staphylococcus epidermidis & 3 & 3 & 3 & 3 & 3 & 0 & 0 & 3 \\
\hline & Staphylococcus epidermidis & 3 & 3 & 3 & 3 & 3 & 3 & 0 & 3 \\
\hline & Staphylococcus epidermidis & 3 & 3 & 3 & 3 & 3 & 3 & 3 & 3 \\
\hline & Staphylococcus epidermidis & 3 & 3 & 3 & 3 & 3 & 3 & 0 & 3 \\
\hline & Staphylococcus epidermidis & 3 & 3 & 3 & 3 & 3 & 0 & 0 & 3 \\
\hline & Staphylococcus epidermidis & 3 & 3 & 3 & 3 & 3 & 3 & 3 & 3 \\
\hline & Staphylococcus haemolyticus & 1 & 2 & 2 & 3 & 3 & 0 & 3 & 3 \\
\hline & Kocuria varians & 3 & 3 & 3 & 3 & 3 & 3 & 3 & 3 \\
\hline & Lactococcus garvieae & 3 & 3 & 3 & 3 & 3 & 3 & 3 & 3 \\
\hline & Kocuria kristinae & 3 & 3 & 3 & 3 & 0 & 0 & 3 & 3 \\
\hline \multirow{10}{*}{2018} & Escherichia coli & 3 & 0 & 1 & 3 & 3 & 3 & 0 & 3 \\
\hline & Escherichia coli & 3 & 3 & 1 & 3 & 3 & 2 & 0 & 3 \\
\hline & Escherichia coli & 3 & 0 & 0 & 3 & 3 & 0 & 0 & 3 \\
\hline & Kocuria varians & 3 & 3 & 2 & 0 & 0 & 0 & 0 & 3 \\
\hline & Kocuria varians & 3 & 3 & 3 & 0 & 1 & 3 & 0 & 3 \\
\hline & Kocuria rbirophila & 3 & 2 & 3 & 0 & 0 & 0 & 0 & 3 \\
\hline & Kocuria rbirophila & 3 & 3 & 3 & 0 & 1 & 0 & 0 & 3 \\
\hline & Micrococcus luteus & 3 & 1 & 3 & 2 & 3 & 0 & 3 & 3 \\
\hline & Burkholderia cepacia & 3 & 3 & 3 & 3 & 3 & 2 & 3 & 3 \\
\hline & Sphingomonas paucimobilis & 3 & 3 & 0 & 3 & 3 & 3 & 3 & 3 \\
\hline
\end{tabular}

Note: The numbers in the table indicate AMR.

$0=$ Resistant, $1=$ Insensitive, $2=$ Moderate sensitive, $3=$ Susceptibility

\section{DISCUSSION}

In the current research, 25 different microorganisms were isolated from cattle mastitis upon the approval of Afyon Kocatepe University Faculty of Veterinary Medicine diagnostic and analysis laboratory. According to Stevens (2018), since bacterial contaminations are the principal cause of cattle mastitis, antimicrobial treatment was identified as the appropriate control and prevention method for this disorder. Prompt therapy with efficient antimicrobials was identified as a crucial approach to minimize the threat of fatal effect, particularly for Gram (+) bacterial impurities. Nevertheless, regardless of the most effective antimicrobial therapies, failures of bacterial treatment are usual. According to WHO (2015), the adoption of antimicrobial agents is related to the threat of prompting the opposition to antimicrobial causes amongst bacteria. There was a substantial proportion of bacteriologically negative results which was in line with other reviewed studies (Seyedmousavi et al. 2018). The probable explanations for bacteriologically negative results in the milk trials could be the occurrence of antibacterial constituents in the milk which led to a reduction in the bacterial viability in the culture or inefficiency in conventional culture as likened to the recognition of bacterial by use of real-time polymerase sequence response (Seyedmousavi et al. 2018). There was a strong correlation between the isolated mastitis agents of cattle and big farm size. Rapid variations in administration approaches that is from tie-stalls to free-stalls have been manifested from 2014 to 2018 thus explaining the cohabitation of environmental agents (Alvarez-Uria et al. 2018). Even though teat decontamination as well as dry treatment is a usual method in Turkish farms, appropriate eradication techniques for the emerging cattle mastitis were not suitably implemented. A increasing proportion of findings shows that the new emerging mastitis agents was associated with farms with less than 30 cattle (Gopal et al. 2015). Catalase test, coagulase assessment, Gram staining as well as recovery of isolates approaches for antimicrobial susceptibility examination were adopted in this research. These techniques are broadly implemented for recognition 
of the susceptibility of animal pathogens, particularly in clinical studies when it is important to decide the most appropriate therapy (Cavassin et al. 2015). However, the outcomes were reported on a qualitative basis and subtle variations in susceptibility were not obvious. As a result, over-dependence on the implementation of antimicrobial to decrease the impact of mastitis in cattle was not maintainable. The AMR was determined in 25 cattle mastitis isolates. Vancomycin and daptomycin antibiotics which are significant for use by a human were examined for Gram (+) cocci. On the other hand, polymyxin B and imipenem antibiotics were assessed for Gram (-) bacteria. The grain straining approach depicted that Streptococcus uberis had the highest AMR while Globicatella sulfidifaciens had the least AMR. The current study emphasized the worrying trend of AMR rates increases in dairy cattle in Turkey.

There are inadequate techniques in handling mastitis which needs to be enhanced due to the culture which is quite tiresome. In addition, to recognize the pathogens, responses such as PCR are to be done independently for different pathogens. The case of mastitis has seen many countries become economic dwarf each year (Erbaş et al. 2017). Loses due to mastitis are not only on the reduction of milk but also lead to further expenditures which include treatments of the disease and quarantine of animals deemed to be diseased. Bovine mastitis is common in Turkey among other nations affecting dairy cattle worldwide with most countries relying on antimicrobial therapy tool for mastitis. It is, however, worthy to note that change of farm culture in firms as mastitis is not only a dairy issue. Researchers from the Penn state have given a recommendation on the infusion of cephapirin benzathine, which should be administered during the stage of winning in the way of limiting mastitis during the preceding lactation (Pohlmann et al. 2018). However, this can work in reducing existing infections other than new ones. Another study done in Oklahoma suggested an intra-muscular injection of antibiotics (oxy-tetracycline) during the winning stage as a way of mitigating mastitis (Dhikusooka et al. 2016). However, the drug did not work as expected as almost $54 \%$ of cows were infected at winning while the remaining percentage was infected at their calving stage.

The outcome of the present research identified the necessity for advancements in antimicrobial management as well as infection regulation plans in dairy farms to decrease the development of AMR. In conclusion; the current study recommends critical control points to include the following; enough nutrition which is balanced so as to stabilize immunity, firms should observe hygiene quality in their facilities and pastures as a way of limiting opportunistic diseases for udder as well as reducing fly breeding sites. The study depicts that the number of emerging cattle mastitis is directly proportional to the size of the herd. The emerging new dairy cattle mastitis in Turkey is an associate of the general hygiene guidelines not being pursued.

\section{REFERENCES}

Alvarez-Uria G, Gandra S, Mandal S, Laxminarayan R. Global forecast of antimicrobial resistance in invasive isolates of Escherichia coli and Klebsiella pneumonia. Int J Infect Dis. 2018; 68: 50-53.

Cheng J, Herman Qu W, Barkema HW, Nobrega DB, Gao J, Liu G1, De Buck J, Kastelic JP3, Sun H4, Han B. Antimicrobial resistance profiles of 5 common bovine mastitis pathogens in large chinese dairy herds. J Dairy Sci. 2019; 1-11.

Cavassin ED, de Figueiredo LF, Otoch JP, Seckler MM, de Oliveira RA, Franco FF, Marangoni VS, Zucolotto V, Levin AS, Costa SF. Comparison of methods to detect the in vitro activity of silver nanoparticles (AgNP) against multidrug resistant bacteria. J Nanobiotechnology. 2015; $13(1): 64$.

Clinical and Laboratory Standards Institute (CLSI). Performance standards for antimicrobial susceptibility testing: 25th informational supplement. CLSIdocument m100-s25, 2015.

Clinical and Laboratory Standards Institute (CLSI). Performance standards for antimicrobial susceptibility testing, 26th edition. 950 West Valley Road, Suite 2500, Wayne, PA 19087 USA, 2016.

Das A, Guha C, Biswas U, Jana PS, Chatterjee A, \& Samanta I. Detection of emerging antibiotic resistance in bacteria isolated from subclinical mastitis in cattle in West Bengal. Vet World. 2017; 10 (5): 517-520.

Du J, Wang $\mathrm{X}$, Luo $\mathrm{H}$, Wang $\mathrm{Y}$, Liu $\mathrm{X}$, Zhou $\mathrm{X}$. Epidemiological investigation of non-albicans Candida species recovered from mycotic mastitis of cows in Yinchuan, Ningxia of China. BMC Vet Res. 2018; 14 (1): 251.

Dhikusooka MT, Ayebazibwe C, Namatovu A, Belsham GJ, Siegismund HR, Wekesa SN, Balinda SN, Muwanika VB, Tjørnehøj K. Unrecognized circulation of sat 1 Foot-and-Mouth Disease virus in cattle herds around Queen Elizabeth National Park in Uganda. BMC Vet Res. 2016; 12 (1): 5.

Eldesouky I, Mohamed N, Khalaf D, Salama A, Elsify A, Ombarak R, El-Ballal S, Effat M, Al Shabrawy M. Candida mastitis in dairy cattle with molecular detection of Candida albicans. Kafkas Univ J Fac Vet Med. 2016; 22 (3): 461-4.

Erbaş G, Parın U, Kirkan Ş, Savaşan S, Özavci V, Yüksel HT. Identification of candida strains with nested pcr in bovine mastitis and determination of antifungal susceptibilities. Turkish J Vet Anim Sci. 2017; 41 (6): 757-763.

Gao J, Barkema HW, Zhang L, Liu G, Deng Z, Cai L, Shan R, Zhang S, Zou J, Kastelic JP, Han B. The incidence of clinical mastitis and distribution of pathogens on large Chinese dairy farms. J Dairy Sci. 2017; 100 (6): 47974806.

Gopal N, Hill C, Ross PR, Beresford TP, Fenelon MA, Cotter PD. The prevalence and control of Bacillus and related spore-forming bacteria in the dairy industry. Front Microbiol. 2015; 6: 1418. 
Hosseinzadeh S, Saei HD. Staphylococcal species associated with bovine mastitis in the north west of Iran: Emerging of Coagulase-Negative Staphylococci. Inte J Vet Sci Med. 2014; 2 (1): 27-34.

Kaur R, Dhakad MS, Goyal R, Haque A, Mukhopadhyay G. Identification and antifungal susceptibility testing of Candida species: A comparison of Vitek-2 system with conventional and molecular methods. J Glob Infect Dis. 2016; 8 (4): 139-146.

Kadariya J, Smith T, Thapaliya D. Staphylococcus aureus and staphylococcal food-borne disease: An ongoing challenge in public health. Biomed Res Int 2014: 827-965.

Ksouri S, Djebir S, Hadef Y, Benakhla A. Survey of bovine mycotic mastitis in different mammary gland statuses in two north-eastern regions of Algeria. Mycopathologia. 2015; 179 (3-4): 327-331.

Martí-Carrizosa M, Sánchez-Reus F, March F, Cantón E, Coll P. The implication of Candida parapsilosis FKS1 and FKS2 mutations in reduced echinocandin susceptibility. Antimicrob Agents Chemother. 2015; 59 (6): 3570-3573.

Martin P, Barkema HW, Brito LF, Narayana SG, Miglior F. Symposium review: Novel strategies to genetically improve mastitis resistance in dairy cattle. J Dairy Sci. 2018; 101 (3): 2724-2736.

Pohlmann A, Starick E, grund C, Höper D, Strebelow G, Globig A, Staubach C, Conraths FJ, Mettenleiter TC, Harder T, Beer M. Swarm incursions of reassortants of Highly Pathogenic Avian Influenza Virus strain H5N8 and H5N5, Clade 2.3. 4.4 B, Germany, Winter 2016/17. Sci Rep. 2018; 8 (1): 15.

Quinn PJ, ME Carter, B Markey, GR Carter. Bacterial Pathogens: Microscopy, Culture, And Identification. In: Clinical Veterinary Microbiology. Mosby, London, UK, Pp. 1999; 21-67.

Rocha MFG, Alencar LP, Paiva MAN, Melo LM, Bandeira SP, Ponte YB, Sales JA, Guedes GM, Castelo-Branco DS, Bandeira TJ, Cordeiro RA, Pereira-Neto WA, Brandine GS, Moreira JL, Sidrim JJ, Brilhante RS. Cross-resistance to fluconazole induced by exposure to the agricultural azole tetraconazole: An environmental resistance school?. Mycoses. 2016; 59 (5): 281-290.

Sağlam A. G, Şahin M, Çelik E, Çelebi Ö, Akça D, \& Otlu S. The role of staphylococci in subclinical mastitis of cows and lytic phage isolation against to Staphylococcus aureus. Veterinary world, 2017; 10 (12): 1481.

Sartori LCA, Santos RC, Marin JM. Identification of Candida species isolated from cows suffering mastitis in four Brazilian states. Arquivo Brasileiro De Medicina Veterinária E Zootecnia. 2014; 66 (5): 1615-1617.

Seyedmousavi S, Bosco SMG, de Hoog S, Ebel F, Elad D, Gomes RR, Jacobsen ID, Jensen HE, Martel A, Mignon B, Pasmans F, Piecková E, Rodrigues AM, Singh K, Vicente VA, Wibbelt G, Wiederhold NP, Guillot J. Fungal infections in animals: A patchwork of different situations. Med Mycol. 2018; 56 (suppl-1): 165187.

Sonmez M, \& Erbas G. Isolation and identification of Candida spp. from mastitis cattle milk and determination of antifungal susceptibilities. Int J Vet Sci. 2017; 6 (2): 104107.

Schukken Y, Chuff M, Moroni P, Gurjar A, Santisteban C, Welcome F, Zadoks RN. The "other" Gram-negative bacteria in mastitis: Klebsiella, Serratia, and more. Vet Clin North Am Food Anim Pract. 2014; 28: 239-256.
Stevens M. Antimicrobial consumption on flemish dairy herds: Quantification, associated factors and mastitis management input as a basis for appropriate use (doctoral dissertation, Ghent University). 2018.

Sztachańska M, Barański W, Janowski T, Pogorzelska J, Zduńczyk S. Prevalence and etiological agents of subclinical mastitis at the end of lactation in nine dairy herds in North-East Poland. Pol J Vet Sci. 2016; 19 (1): 119-124.

Vikram A, Bomberger J, Bibby KJ. Efflux as a glutaraldehyde resistance mechanism in Pseudomonas fluorescens and Pseudomonas aeruginosa biofilms. Antimicrob Agents Chemother. 2015; 59 (6): 3433-40.

Xiao Fan X, Chen SC, Wang H, Sun ZY, Liao K, Chen SL, Yan Y, Kang M, Hu ZD, Chu YZ, Hu TS, Ni YX, Zou GL, Kong F, Xu YC. Antifungal susceptibilities of Candida glabrata species complex, Candida krusei, Candida parapsilosis species complex and Candida tropicalis causing invasive candidiasis in China: 3-year national surveillance. J Antimicrob Chemother. 2014; 70 (3): 802-810.

World Health Organisation (WHO). Global Action Plan On Antimicrobial Resistance. 2015. Retrieved from http: //www .who .int/drug resistance/global action.

Zhang S, Piepers S, Shan R, Cai L, Mao S, Zou J, Ali T, De Vliegher S, Han B. Phenotypic and genotypic characterization of antimicrobial resistance profiles in Streptococcus dysgalactiae isolated from bovine clinical mastitis in 5 provinces of China. J Dairy Sci. 2018; 101 (4): $3344-335$. 